УДК 130.2:316.6 316.277:159.923.2

DOI 10.35423/2078-8142.2018.3-4.02

3. В. Шевченко, кандидат філософських наук, дочент, дочент кафедри філософії та релігієзнавства Черкаського начіонального університету імені Богдана Хмельницького м. Черкаси, Україна ORCID: http://orcid.org/0000-0001-9980-4372

\title{
ЧУЖИЙ ЯК ЧИННИК ТВОРЕННЯ СОЦІАЛЬНОЇ ІДЕНТИЧНОСТІ ОСОБИСТОСТІ (ТРАДИЦІ ФЕНОМЕНОЛОГІЧНОЇ СОЦІОЛОГІї)
}

У статті розкрито значущість аналізу феномена Чужого для дослідження соціальної ідентичності особистості. Сучасне дослідження теми соціальної ідентичності неможливе без урахування досвіду феноменологічної традиції визначення смислових підстав такої ідентичності. Бернгард Вальденфельс акцентує увагу на принциповій неможливості зафіксувати певні характеристики Чужого, підкреслює комунікативний, респонзивний характер визначення Чужого. Альфред Шюи розкриває структурний характер утвердження соиіальної ідентичності. Смислову структуру соиіальної ідентичності визначає тип соиіальних зв'язків, в яких залучена особистість - передусім міра наближення чи віддалення Іншого, яка може варіюватися від близької людини до Чужого.

Ключові слова: сочіальна ідентичність, Чужий, Інший, структура сочіальної ідентичності, феноменологічна соціологія.

Сучасне дослідження теми соціальної ідентичності неможливе без урахування досвіду феноменологічної традиції визначення смислових підстав такої ідентичності. Тема Чужого як смислового конструкту та моделі партнера соціальної взаємодії є ключовою для феноменологічної 
соціології, яка розгорнула дослідження царини соціального методами феноменологї.

До класиків феноменологічної соціології, які докладно досліджували тему Чужого, належать передусім Альфред Шюц та Бернгард Вальденфельс. Утім, для кращого осягнення їхнього бачення феномена Чужого, неминуче потрібно згадати, що витоки цієї проблематики знаходимо у концепті інтерсуб'єктивності Едмунда Гусерля, тоді як основні наслідки для дослідження суспільства та культури дає аналіз проблеми чужого під кутом зору комунікативної парадигми [1], яка саме і формується на грунті переосмислення феноменологічної теоретичної спадщини.

Отже, у цій статті з'ясуємо, як саме аналіз феномена Чужого дає можливість досліджувати структуру соціальної ідентичності як динамічну i, водночас, певною мірою підконтрольну зусиллям особистості упорядкувати свій соціальний світ.

Свою працю «Топологія чужого» [2] німецький та американський філософ і соціолог Бернгард Вальденфельс починає 3 констатації тієї обставини, що «за передумов обмежених порядків Чуже стає помітним у вигляді чогось поза-порядкового (Außer-ordentlichen), що в різні способи виникає на краях і в дірках різних порядків (Ordnungen)» [2, с. 6]. Українська дослідниця С. М. Гатальська у своєму підручнику «Філософія культури» слушно резюмує щодо позиції Вальдефельса: ««Чужий»є феноменом, який кидає нам виклик тим, що виходить за межі розуміння. Чуже постає як інстанція; вона очікує й вимагає відповіді, провокує, мотивує, домагається нас» $[3,250]$. Справді, Вальденфельс наголошує на невловимості чужого як феномена для нашого розуміння: «Чуже не можна порівняти не тому, що воно є цілком іншим, а тому, що домагання Чужого ухиляється від будь-якого порівнювання та вирівнювання» [2, c. 9].

На прикладі аналізу культури Вальденфельс демонструє, як феномен чужого формує власну самість, «своїсть» певної соціальної ідентичності: «Своєю своєрідністю культура завдячує відповіді на чужорідне, яке може походити зі своєї традиції або з чужих традицій... Відповідь включає прислуховування (Hören) до голосу Чужого, але не залежність від нього (Hörigkeit); адже відповіді, які ми даємо, мають бути винайденими (zu erfinden), а не просто віднайденими (wiederzufinden). Водночас те, на що ми відповідаємо та маємо відповідати, не в наших 
руках і не виникає в нашому вільному винаході. Наша своїсть, яка виростає 3 відповіді, має свій центр ваги поза собою в Чужому, на яке ми відповідаємо. Таким чином, чужість вписана у своїсть» [2, с. 72]. Але якщо в нас самих присутня частка чужого, то можливі дві версії: або ми самі стаємо чужими, або ж маємо вивільнити для чужого в собі якийсь спеціальний простір, тобто ускладнити структуру власної ідентичності, відійти від уявлень про іiі суцільність. На початку свого дослідження Вальденфельс нібито натякає на те, що він приймає першу відповідь, але по ходу свого дослідження феномена чужого він сам надає дедалі більше свідчень на користь другої. Так, спочатку зустрічаємо: «Чуже афікує та інфікує наче вірус значення того слова, до якого воно приєднується або прищеплюється. Зіткнення з Чужим викликає зворотний процес. Досвід, мова, країна, тіло, розум і Я, які можуть виступати як чужі, стають вже не просто такими, якими вони були дотепер. Досвід Чужого, який означає більше, ніж збагачення досвіду, обертається перетворенням досвіду на чужий досвід і перетворенням на Чужого того, хто цей досвід переживає. Чужість у цьому сенсі є заразливою, як хвороба, кохання, ненависть чи сміх» [2, с. 6].

Але порівняння «свого» $\mathrm{i}$ «чужого» не лише вносить частку одного у структуру іншого - воно вимагає залучення третього - щонайменше як свідка цього процесу. Гатальська переконливо демонструє, що концепція Чужого Вальденфельса вбирає в себе європейську традицію адаптації до чужої культури та концептуального осмислення цих процесів: «свою визначеність, або ідентичність, як індивід, так і культура, отримують тільки в стосунках з іншими ідентичностями. Якби між культурами не було певних віддзеркалювань.., то не було б жодного інтеркультурного поля, яке б уможливлювало пізнання власних здатностей завдяки пізнанню Чужого» [3, с. 244].

Саме тому Вальденфельс визначає його як гіперфеномен, тобто такий, який виявляє себе саме тоді, коли ухиляється, вислизає від схоплення. Тобто феномен чужого $є$ не певна субстанція, але іiі втрата, це якась позапорядкова, неподолана відсутність, сутність чужого завжди знаходиться не там, де ми їі вже очікуємо, але в якомусь іншому місці [2, с. 6]. Сам факт необхідності порівняння, наявності відмінності від нашої самості вже свідчить про наявність чужого: «Порівняння вже передбачає щось таке, що вимагає порівняння, що занепокоює, приваблює 
й відштовхує погляд. Порівняння саме є форма відповіді, в якій Чуже вимірюють іншим і порівнюють із ним» [2, с. 91].

Утім, у сенсі інтенціональності, досвід чужого - це завжди обернений досвід свого, оскільки він опирається на стосуннок «своє-чуже». Тому для теорії досвіду чужого необхідна структура стосунку «домагання-відповідь», яка відповідає респонзивності. Змістом респонзивного досвіду чужого $є$ подія відповіді, тобто якщо не відбулась відповідь як подія, то не було досвіду чужого, бо порядок власного не був зачеплений, а чуже домагання не сприйняте. Як зауважує український феноменолог Вахтанг Кебуладзе: «Ця просторова переорієнтація феноменологічної концепції інтерсуб'єктивності і є... головною особливістю філософської концепції Вальденфельса. Пошук Чужого в просторі, а не в часі, в сучасному світі, а не в історії, у світі, де перетинаються різні традиції, а не лише у власній традиції, яка часто-густо заперечує іншій традиції, покликаний вивести нас із того скрутного становища тотального міжкультурного, міжетнічного та міжрелігійного конфлікту, в якому опинилося сучасне людство» [5, с. 198-199].

Таким чином, Вальденфельс феномен інтеркультурності аналізує на основі і за моделлю взаємодії з Чужим, на основі порівняння «своєї» культури 3 «чужою», яка апріорі видається не просто незнайомою, а чужою. Але не лише інтерсуб'єктивні взаємини з чужим він переносить на інтеркультурні взаємини, але й навпаки - закономірності міжкультурної взаємодії прямо переносить на інтерперсональні. «За здійснюваного переходу від індивідуального до культурного досвіду Чужого йдеться не просто про розширення або ускладнення персональних одиничних досвідів у тому сенсі, що інтеркультурність взагалі означає інтерсуб'єктивність» [2, с. 9]. Це відбувається завдяки тому, що і у випадку інтерсуб' єктивності і у випадку інтеркультурності він аналізує царину досвіду, а уже всередині досвіду починає здійснювати аналітичні і феноменологічні розрізнення, відношення «інтер» він заміщає відношеннями «інтра»: «Чужість, яка визначається способом своєї доступності й не передбачає із самого початку надійну територію Свого, «свою сферу», ми зустрічаємо не лише в інших, вона починається у своєму домі як чужість мене самого або як чужість нас самих. Традиційно говорять, що тут ідеться про інтрасуб'єктивну чужість на противагу інтерсуб'єктивній чужості, а їй відповідає інтракультурна 
чужість на противагу інтеркультурній чужості. Як на будь-який досвід, також на досвід самого себе накладаються певні обмеження» [2, с. 21].

«За здійснюваного переходу від індивідуального до культурного досвіду Чужого йдеться про розширення або ускладнення персональних одиничних досвідів у тому сенсі, що інтеркультурність взагалі означає інтерсуб'єктивність» [2, с. 9]. Згідно з Е. Гусерлем, інтерсуб'єктивність тісно взаємопов'язана 3 людською тілесністю: переживання тілесності персоною засвідчує наявність інших тіл, так само, як і інших свідомостей [4]. Сам світ, в якому усвідомлює себе людина, від самого початку постає для неї не як «мій» чи «твій», а як «наш», а тому світ пізнають спочатку не суб'єктивно, а інтерсуб'єктивно. Отже, у феноменологічному проекті Вальденфельса головну роль відіграє поняття відповіді на запит, заклик, домагання, вимогу з боку Іншого, або Чужого. I «Чуже стає тим, чим воно $є$, лише в події відповіді, тобто воно ніколи не може бути повністю й однозначно визначеним» [2, с. 43]. У цьому принципова відмінність його позиції від Гусерлевої. Адже у Гусерля первинними $\epsilon$ чисті феномени, а всяка комунікація - вторинна, як уможливлена цими феноменами. У філософії символічного інтеракціонізму ж навпаки смисли виникають лише 3 конкретики між персональної інтеракції досить звернутися до головної праці Джорджа Герберта Міда [6]. Феноменологія Вальденфельса тут явно йде не за Гусерлем, а за Мідом: на його думку, мовлення дістає смисл лише як відповідь на інше мовлення, дія набуває сенсу лише як інтеракція, тобто як взаємодія з іншим. Навіть якщо я не дію, я все ж таки відповідаю, а саме у негативний спосіб. У цьому сенсі мовчання також є відповіддю. Таким чином, відповідь, а точніше респонзивність як принципова налаштованість на відповідь, притаманна кожній людині, за Вальденфельсом, є універсальним способом існування людини у світі - лише разом з іншими людьми, тобто у спільному світі. Не подія відповіді визначається через «Я» того, хто говорить, а навпаки, «Я» визначає себе через відповідь. Там, де виникають нові думки, вони не належать ні мені, ні Іншому: вони виникають між нами.

Австрійський та американський філософ і соціолог Альфред Шюц розглядав комунікацію інтермонадної єдності найвищого рівня - рівня культури. За основу свого дослідження він взяв приклад особливо складної комунікативної ситуації, в яку потрапляє іммігрант. Пошук методів 
подолання перешкод у такому непростому спілкуванні допоміг австрійському філософу прояснити необхідні умови для встановлення комунікації між людьми. Коли людина іммігрує до іншої країни, вона не може розраховувати на автоматичне залучення до місцевої комунікативної спільноти. Причина полягає в тому, що будь-якому можливому соціальному пристосуванню має передувати знайомство 3 культурним зразком, який містить необхідні передумови життя певної соціальної групи. Цим терміном автор твору «Чужий» позначає «всі ті специфічні цінності, інститути, системи орієнтації і контролю (народні звичаї, закони, звички, традиції, етикет, манери поведінки), які... характеризують - а можливо, навіть конституюють будь-яку соціальну групу в той чи інший момент іï історичного існування» [9, с. 534]. До того ж, сприймаються нею як самозрозумілі.

В основу своєї філософської концепції Шюц поклав протиставлення «свої-чужі», яке несвідомо засвоюється в процесі формування національної, соціальної та всіх інших форм ідентичності. Для того, щоб проаналізувати той шлях соціальної адаптації, який проходить чужинець, Шюц продемонстрував те, яким чином культурний зразок групового життя даний в буденній свідомості людини, яка живе серед «своїх» - відчуває приналежність до спільноти. За такого стану справ знання культурного зразка, що включає знання рецептів інтерпретації соціального світу, поведінки з людьми і обходження з речами, сприймається як саме собою зрозуміле. Культурний зразок надає готові інструкції поведінки, які функціонують одночасно як приписи до дії, тобто виступають як задана суспільством схема самовираження і як схеми інтерпретації діяльності інших індивідів. Проблема полягає в тому, що поведінка людини демонструє, що відповідно до різних соціальних ролей у ній поєднуються часто не поєднувані погляди на світ, політику та соціальні взаємовідносини. На думку Шюца, це є свідченням відсутності гомогенності знання людини в їі повсякденному житті.

Перший крок, який здійснює іммігрант, щоб зблизитись зі сформованою «ми-групою»: він намагається витлумачити культурний зразок цієї соціальної групи і зорієнтуватись в ньому. Оскільки він належить до іншої культури, то він при цьому несвідомо керується засвоєним у процесі своєї соціалізації культурним зразком. Поступово нові соціальні умови набувають інтерпретації в категоріях звичного мислення, що містить неадекватні уявлення про культурний зразок тієї групи, з якою він 
хоче зблизитись. Але такі поняття, що були сформовані за цілковитого відчуження від відповідних культурних умов, на практиці виявляються неадекватними. Рідна схема інтерпретації чужої групи розглядає ії членів як об'єктів, а не як до потенційних самодостатніх співрозмовників. Й тому вона виявляється застарілою в нових соціальних умовах, у живому досвіді і соціальних взаємодіях в межах іншої країни. Тому Шюц наполягає на необхідності залучення більших зусиль чужинця в його спробах інтеграції в іноземну спільноту. По-перше, він має перевизначити базові поняття свого культурного зразку в категоріях, що відповідають новій соціальній реальності. Така інтерпретація також корисна, оскільки дає можливість зрозуміти і запам'ятати деякі елементи нового культурного зразка. По-друге, щоб наблизитись до адекватного погляду на культурний зразок нерідної групи, він має, крім раціонального засвоєння, почати цілеспрямовано діяти згідно з ним. Коли звичаї, цінності та манери поведінки перестануть бути лише змістом мислення й перетворяться на сегмент власного світу, схему власного самовираження, їх буде значно легше засвоїти. В будь-якому випадку Шюц вважає, що «чужому», який намагається засвоїти культурний зразок, навіть за умови здійснення всіх цих кроків не гарантується об'єктивний шанс на успіх у використанні рецептів поведінки. У нього є лише суб'єктивна можливість, яку потрібно крок за кроком перевіряти. Таким чином, поєднання раціонального освоєння і практики допомагає здобути якомога більш експліцитне знання елементів зразка.

Проте, на шляху до виконання цих вимог та подальшого застосування нерідного культурного зразка стоїть чимало перешкод. Оскільки «чужий» не дотримується базових припущень, то він живо відчуває їх незв'язність і суперечливість. Як наслідок він ставить під сумнів майже все, що здається авторитетним для членів тієї групи, 3 якою він хоче зблизитись. Це пояснюється тим, що він не є частиною живої історичної традиції, яка лежить в основі культурного зразка. Сдине, що іммігрант може розділити 3 новою соціальною групою, - це спільне теперішнє та майбутнє. Також у нього відсутній статус в ієрархії цієї соціальної групи, він не належить до ії «ми» - не може уявити себе центром соціального оточення. Це заважає йому прийняти ті типові і анонімні установки, виконання яких очікують члени нерідної групи від партнера з кому- 
нікації у типовій ситуації. Спільні минулі переживання створюють недоступний для повноцінного засвоєння код.

За аналогією з культурою певної національної групи можна віднайти подібний зразок, що керує індивідуальною поведінкою кожної окремої особистості, у структурах іiі свідомості. Про це писав Гусерль, коли зазначав, що кожна людина має власний неповторний досвід, тобто володіє своїми явищами (актами переживань предметів, думок та цінностей), своїми феноменами (переживаннями) світу. Тому не можна стверджувати, що пізнання культурного зразка $є$ достатньою умовою для успішної комунікації. Така комунікація завжди потребує індивідуального підходу, розгляд якого оминає Шюц, оскільки фокусує увагу на типових комунікативних ситуаціях. Тим не менше і в його праці «Чужий» простежується розуміння того, що крім вторинних значень, котрі походять від контексту та соціального оточення, комунікація містить відтінки, які пов'язані з конкретними умовами ії перебігу. Тобто в ній не можна покладатись навіть на усталене в певній спільноті розуміння слів, адже кожна людина може надавати перевагу одній з безлічі можливих дефініцій. Саме поняття «типовості» стає проблематичним під тиском непередбачених реакцій, які можуть виникати під впливом емоцій або, за Гусерлем, специфічно-суб'єктивних переживань.

Шюц критикує і не сприймає ситуацію в науці і філософії, що склалася в другій половині XX ст., коли суспільство сприймалося як зовнішній об'єкт, до якого можна застосувати природничо-наукову методологію. Під впливом ідей Макса Вебера та Гусерля, він засновує феноменологічну соціологію, завданням якої є подолання пануючої раціоналістичної парадигми. Вихідна посилка феноменологічної соціології протиставляється ідеям структурно-функціональної соціології: індивід не є бранцем соціальної структури, соціальна реальність постійно відтворюється людьми, залежна від нашої свідомості і наших інтерпретацій. Кожна людина «занурена» у «життєвий світ», у світ повсякденної реальності. Життєвий світ - це наше безпосереднє «інтуїтивне середовище», де «Я - людська істота, що народилася і живе в соціальному світі 3 його повсякденністю, сприймає його готовим, збудованим до мене, відкритим для моєї інтерпретації і дії, завжди співвіднесеним з моєю актуальною біографічно детермінованою ситуацією. Тільки щодо мене певний вид зв'язків з іншими набуває того особливого сенсу, який я позначаю словом «ми». Тільки щодо «нас», де центром $є$ я, інші виступають 
як «ви». А щодо «вас», які своєю чергою співвідносяться зі мною, вирізняється третя сторона - «вони» [7, с. 133]. У життєвому світі немає визначень, є лише почуття.

Важливою характеристикою життєвого світу $\epsilon$ інтерсуб'єктивність, що означає, що людина розділяє світ разом з іншими людьми, сприймає його як загальний для всіх. Інтерсуб'єктивність - це соціальність, внутрішньо притаманна свідомості людей. Однак соціальний світ не лише є інтерсуб'єктивним, а й являє собою втілення міжсуб'єктної взаємодії людей у досвіді їх повсякденного життя. Навіть найближча людина, як відзначає Шюц, є для мене чужим «Я»: «перебіг переживань моєї ближньої людини я схоплюю лише «опосередковано», витлумачуючи iї рухи, iї вирази, iї повідомлення як ознаки суб'єктивно осмислених одиничних досвідів чужого Я» [8, с. 77]. Установка Я по відношенню до чужої діяльності, на думку А.Шюца, визначається як установка на Чужого. Шюц розвиває ідею градації близькості і дальності оточуючих нас Інших у життєвому світі. «Альтер его» - це та група Інших, яка найбільш наближена до мого Я: наші знайомі, сучасники, товариші, тобто всі ті, хто перебуває з нами в загальному зовнішньому і внутрішньому часі, і чий психічний внутрішній світ я можу осягнути. Шюц твердить, що у «ми-відношенні» «інший сприймається як унікальна індивідуальність, нехай і розкривається лише фрагментарно, виявляючи лише один з аспектів своєї особистості в унікальній біографічної ситуації. У всіх інших формах соціальних відносин (і навіть у відносинах між партнерами, поки йдеться про нерозкриті сторони особистості іншого) «я» іншої людини можна вловлювати лише за допомогою «уявного внесення гіпотетичного явища сенсу» (якщо вдатися до вислову Уайтхеда). Іншими словами, ми розуміємо іншого, конструюючи типовий спосіб діяльності, типові, що лежать в його основі, мотиви, установки типу особистості. Інший і його дії, недоступні моєму безпосередньому спостереженню, пояснюються при цьому як прості приклади, зразки даного типу особистості» [7, с. 134]. Таким чином, Шюц структурує соціальну ідентичність через спосіб іiі утворення, диференціюючи взаємини «ми», «ви», «вони», сучасники, попередники, нащадки тощо. Зрозуміло, що у цих різних стосунках ми отримуємо, як правило, дещо іншу соціальну ідентичність - але все ж різною мірою, але всі ці різновиди соціальної ідентичності є обов'язковими складовими структури 
нашої власної ідентичності - як підстави для смислової диференціації, яке уможливлює диференціацію нашої соціальної поведінки.

Розвитком проекту посткласичної феноменології стала респонзивна феноменологія Б.Вальденфельса, у межах якої ключове значення набуває не так інтенціональний досвід, як респонзивна відмінність.

Вальденфельс розвиває положення Шюца, загострюючи не типовість інтерперсональної комунікації і водночас вписуючи іiі в інтрасуб'єктвині та інтракультурні патерни поведінки та відповідні смислові зв'язки. Для Вальденфельса ні інтенціональний досвід у класичній трансцендентальній феноменології, ні комунікативні проекти аналітичної філософії не здатні наблизити нас до розуміння «чужого» як «чужого». У рамках цих підходів «чуже» виявляє себе відповідно як дещо-ще-незрозуміле і як «виняток у системі правил», тобто регульоване відхилення від правила. В обох випадках залишається прихованою сутність «чужого». Чуже, за Вальденфельсом, має три основні характеристики: 1) те, що відбувається поза своєю цариною; 2) те, що належить Іншому; 3) те, що $є$ чужого роду. Таким чином, Чуже для Вальденфельса $є$ те, що знаходиться не в своєму місці, завжди десь в іншому місці. Чуже показує себе особливим чином - є собою в показуванні себе, але не розчинюється в тому, щзо себе показує. Саме таке розуміння напряму визначення соціальної ідентичності як основаного на дослідженні феномена Чужого виводить, на нашу думку, на визначення успішної соціальнофілософської методології осмислення концепту множинної соціальної ідентичності.

\section{ЛITEPАТУРА}

1. Бойченко M. I. Комунікативна парадигма дослідження культури // Українські культурологічні студії. 2018. № 1 (2). С. 5-9.

2. Вальденфельс Б. Топографія чужого: студії до феноменології Чужого. К. : ППС-2002, 2004. 206 c.

3. Гатальська С. М. Філософія культури. Підручник. К. : Либідь, 2005. $328 \mathrm{c.}$

4. Гуссерль Э. Картезианские размышления. СПб. : Наука. Ювента, 1998. $315 \mathrm{c}$.

5. Кебуладзе В. Бернгард Вальденфельс - феноменолог Чужого. Післямова перекладача // Вальденфельс Б. Топографія чужого: студії до феноменології Чужого. К. : ППС-2002, 2004. С. 198-202. 
6. Мід Дж.Г. Дух, самість і суспільство. 3 точки зору соціального біхевіориста. К. : Український центр духовної культури, 2000. 374 с.

7. Шюи А. Структура повседневного мышления // Социологические исследования. 1988. № 2. С. 129-137.

8. Шюи А., Лукман Т. Структури життссвіту. К. : Український Центр духовної культури, 2004. 560 с.

9. Шюи А. Чужак: социально-психологический очерк // Шюц А. Избранное: мир, светящийся смыслом. М. : РОССПЭН, 2004. С. 533-549.

\section{REFERENCES}

Boychenko M. I. (2018). The communicative paradigm of cultural research. Ukrayins'ki kul'turolohichni studiyi (Ukrainian Cultural Studies), 1(2), 5-9. [In Ukrainian].

Waldenfels B. (2004). The Topography of the Alien: Studies in the Phenomenology of the Alien. Kyiv. [In Ukrainian].

Gatalskaya S. M. (2005). Philosophy of Culture. Textbook. Kyiv: Libid. [In Ukrainian].

Husserl E. (1998). Cartesian Reflections. St. Petersburg: Science. Juventa. [In Russian].

Kebuladze V. (2004). Bernhard Waldenfels is a phenomenologist of the Stranger. Afterword of the translator. In Waldenfels B. Topography of a stranger: Studies in the phenomenology of a stranger. Kyiv, 198-202. [In Russian].

Mead Jg. (2000). The Spirit, Self and Society. From the point of view of the social-behaviourist. Kyiv: Ukrainian Center for Spiritual Culture. [In Ukrainian].

Schutz A. (1988). The Structure of Everyday Thinking. Sotsiologicheskiye issledovaniya (Sociological Studies), 2, 129-137. [In Russian].

Schutz A., Luckman T. (2004). Structures of the lifeworld. Kyiv: Ukrainian Center for Spiritual Culture. [In Ukrainian].

Schütz A. (2004). Stranger: a socio-psychological essay. In Schütz A. Selected: a world shining with meaning. Moscow: ROSSPEN, 533-549. [In Russian]. 


\title{
Shevchenko Zoya
}

Candidate of Philosophical Sciences (Ph. D.), Associate Professor of the Department of Philosophy and Religious Studies, B.Khmelnitsky' Cherkasy National University, Cherkasy Ukraine; ORCID: http://orcid.org/0000-0001-9980-4372

\section{Stranger as a factor in creating of person's social identity (tradition of phenome- nological sociology).}

\begin{abstract}
The article reveals the significance of the analysis of the phenomenon of a stranger for the study of social identity of the individual. A modern study of the topic of social identity is impossible without taking into account the experience of the phenomenological tradition of determining the semantic grounds for such an identity. Bernhard Waldenfels emphasizes the fundamental impossibility of fixing certain characteristics of Stranger, emphasizes the communicative, reciprocal character of the definition of Stranger. He views responsiveness as a principled disposition to the response inherent in each person, as a universal way of being human in the world - only with other people, that is, in the common world. The author notes that for Waldenfels neither the intentional experience in classical transcendental phenomenology nor the communicative projects of analytical philosophy are capable of approaching the understanding of "alien" as "alien". Within these approaches, the "alien" manifests itself, respectively, as a somewhat-yet-not-clear and as an "exception in the rule system", ie a regulated deviation from the rule. Alfred Schutz reveals the structural nature of the assertion of social identity, develops the idea of grading the closeness and distance of others around us in the world of life. It structures social identity through the way it is formed, differentiating between "we", "you", "they", contemporaries, predecessors, descendants, and more. The semantic structure of social identity defines the type of social ties in which the person is involved - first of all, the degree of approaching of the Other, which can range from a close friend to a Stranger. Therefore, the author concludes that, according to Schütz, in these different relationships we tend to receive a somewhat different social identity, but to a different extent. All these varieties of social identity are indispensable components of the structure of our own identity - as a basis for meaningful differentiation that allows differentiation of our social behavior.
\end{abstract}

Keywords: social identity, Stranger, Other, structure of social identity, phenomenological sociology. 


\section{Шевченко Зоя}

кандидат философских наук, доиент, доиент кафедры философии и религиоведения, Черкасский национальный университет имени Богдана Хмельниикого, Черкассы, Украина; ORCID: http://orcid.org/0000-0001-9980-4372

\section{Чужсой как фактор создания социальной идентичности личности (тра- диция феноменологической социологии)}

\section{Аннотация}

В статье раскрыта значимость анализа феномена Чужого для исследования сочиальной идентичности личности. Современное исследование темы социальной идентичности невозможно без учета опыта феноменологической традищии определения смысловых оснований такой идентичности. Бернхард Вальденфельс акиентирует внимание на принципиальной невозможности зафиксировать некоторые характеристики Чужого, подчеркивает коммуникативный, респонзивний характер определения Чужого. Шюи раскрывает структурный характер утверждения социальной идентичности. Смысловую структуру соииальной идентичности определяет тип соџиальных связей, в которых вовлечена личность - прежде всего мера приближения или удаления Другого, которая может варьироваться от близкого человека до Чужого.

Ключевые слова: сочиальная идентичность, Чужой, Другой, структура социальной идентичности, феноменологическая сочиология. 